\title{
Drying kinetics of soybean grains
}

\section{Cinética de secagem dos grãos de soja}

\section{Lays Português SILVA'; Samuel Gonçalves Ferreira dos SANTOS ${ }^{2}$; Juliano Silva QUEIROZ ${ }^{3}$; Renato Souza RODOVALHO ${ }^{4}$; Wilian Henrique Diniz BUSO ${ }^{4}$}

\author{
${ }^{1}$ Autor para correspondência, acadêmica do curso de Agronomia, Instituto Federal Goiano - Campus Ceres, \\ lysmenezes94@gmail.com \\ ${ }^{2}$ Autor para correspondência, acadêmico do curso de Agronomia, Instituto Federal Goiano - Campus Ceres, samuel- \\ 2100@hotmail.com \\ ${ }^{3}$ Acadêmico do curso de Agronomia, Instituto Federal Goiano - Campus Ceres, julianoagro260@gmail.com \\ ${ }^{4}$ Doutor em Agronomia, IF Goiano - Campus Ceres, renato.rodovalho@ifgoiano.edu.br \\ ${ }^{5}$ Doutor em Ciência Animal, IF Goiano - Campus Ceres, wilian.buso@ifgoiano.edu.br
}

Recebido em: 03-07-2019; Aceito em: 29-01-2020

\begin{abstract}
Soybean (Glycine max) is one of the most important crops in grain production in Brazil. Its grains are destined for the domestic market and mainly for export. Thus, it is necessary to guarantee the quality of stored grains for later consumption. Drying is a preprocessing step to preserve grains and improve their quality during storage. This study evaluates the drying kinetics of soybean grains to determine effective diffusivity and thermodynamic properties. Soybean samples were collected at the Federal Institute of Goiás - Ceres Campus. Moisture content was approximately 0.21 (decimal db). The samples were subjected to drying at temperatures of $20,30,40$, and $50^{\circ} \mathrm{C}$ until hygroscopic equilibrium was reached. Ten mathematical models were used to fit the drying data, using the following statistical criteria: relative mean error $(P)$, estimated mean error (SE), chi-square $\left(X^{2}\right)$, coefficient of determination $\left(\mathrm{R}^{2}\right)$, and residual distribution. The effective diffusion coefficient and the activation energy were obtained through the selected mathematical model and the Arrhenius equation. The dryings started with RX close to 0.82 and finished with hygroscopic equilibrium. The average drying time was 9 hours and 30 minutes. The mathematical model of Midilli best fit the drying kinetics of soybean grains. The activation energy obtained was $26.80 \mathrm{~kJ} \mathrm{~mol}^{-1}$, standard for agricultural products. As the drying air temperature rises, the effective diffusion coefficient increases from $2.264210^{-9}$ to $5.632510^{-9} \mathrm{~m}^{2} \mathrm{~s}^{-1}$, common values for grains. The increase in the drying air temperature increases Gibbs free energy while decreasing enthalpy and entropy, a behavior common to grains for different temperatures.
\end{abstract}

Additional keywords: enthalpy; entropy; Gibbs free energy; mathematical modeling; water diffusivity.

\section{Resumo}

A soja (Glycine max) é uma das culturas de extrema importância na produção de grãos no Brasil. Seus grãos são destinados para comercialização interna e, principalmente, para exportação. Por isso se faz necessário garantir a qualidade dos grãos armazenados para seu consumo posterior. A secagem é uma pré etapa de beneficiamento dos grãos com o intuito à conservação e a qualidade durante o armazenamento. Objetivou-se com este trabalho avaliar a cinética de secagem dos grãos de soja, determinar sua difusividade efetiva e suas propriedades termodinâmicas. As amostras de soja foram colhidas no Instituto Federal Goiano - Campus Ceres, tendo como teor de água aproximadamente 0,21 decimal em base seca (b.s). As amostras foram submetidas a secagem nas temperaturas de $20,30,40$ e $50^{\circ} \mathrm{C}$ até o alcance do equilíbrio higroscópico. Dez modelos matemáticos foram utilizados para o ajuste dos dados da secagem, utilizando como critério estatístico: erro médio relativo $(P)$, erro médio estimado (SE), qui-quadrado $\left(X^{2}\right)$, coeficiente de determinação $\left(R^{2}\right)$, e a distribuição do comportamento dos resíduos. Através do modelo matemático selecionado e da equação de Arrhenius, obteve-se o coeficiente de difusão efetiva e a energia de ativação. As secagens iniciaram com RX próximo a 0,82 e encerraram com equilíbrio higroscópico. O tempo médio de secagem foi de 9 horas e 30 minutos. O modelo matemático que melhor se ajusta a cinética secagem de grãos de soja foi o de Midilli. A energia de ativação obtida foi de $26,80 \mathrm{~kJ} \mathrm{~mol}^{-1}$, padrão para produtos agrícolas. O coeficiente de difusão efetivo aumenta de 2,2642 $10^{-9}$ para $5,632510^{-9} \mathrm{~m}^{2} \mathrm{~s}^{-1} \mathrm{com}$ a elevação da temperatura do ar de secagem, valores comuns para grãos. $\mathrm{O}$ incremento da temperatura do ar de secagem aumenta a energia livre de Gibbs, enquanto diminuem a entalpia e a entropia, comportamento comum aos grãos para diversas temperaturas.

Palavras-chave adicionais: difusividade da água; entalpia; entropia e energia livre de Gibbs; modelagem matemática. 


\section{Introduction}

Soybean (Glycine max) is a crop with proteinrich grains that has been used in human food and animal feed (Coêlho, 2018). Soybean production is very important in Brazil, with an estimated production of 122.2 million tons for the $2019 / 2020$ harvest, $2.6 \%$ higher than the 2018/2019 harvest (CONAB, 2020).

Ribeiro et al. (2005) highlight some factors to be considered for obtaining quality grains, among them early harvest, thereby reducing field losses from insect and microorganism attack. High moisture content at harvest can be reduced by drying, which is of paramount importance among the techniques involved in preserving the desirable qualities of plant products during their storage period.

Resende et al. (2010) explains that some grain drying methods may affect grain quality. Therefore, studies focus on the development and improvement of grain drying equipment. Drying simulations provide results on the behavior of each plant product during water removal, in which several mathematical models are used to describe the drying kinetics.

This study analyzes water diffusion, in which the grains will be exposed to a certain air temperature, water surface speed, and drying air relative humidity in a thin layer. The theoretical results obtained will be used in mathematical models, which allow estimating the behavior of grain water during drying. These results do not provide data on water and energy transport within the grains and, hence, the study of thermodynamic properties is recommended (Barrozo et al., 2004).

According to Corrêa et al. (2010), the thermodynamic property is important for the development of drying equipment, relating the properties of adsorbed water, the determination of the energy required in this process, the evaluation of food microstructure, and the study of physical phenomena that occur on the surface of a plant product.

The present study evaluates the drying kinetics of soybean grains at temperatures of $20,30,40$, and $50^{\circ} \mathrm{C}$, determining the activation energy, water diffusivity, and thermodynamic properties.

\section{Material and methods}

Samples of grains of soybean cultivar Bayer ${ }^{\circledR}$ TEC Ipro Credenz ${ }^{\circledR}$ were obtained from the experimental crop grow in the area of the Federal Institute of Goiás - Ceres Campus. Sowing was performed in early November 2018 and harvest occurred in late January 2019. The grains were selected and taken to the Industrial Chemistry Laboratory of the Federal Institute of Goiás - Ceres Campus, where the drying experiment began.

Initial grain moisture content was determined in the laboratory using the gravimetric method, in which the grains were taken to a drying oven with forced air circulation and exposed to a temperature of $105 \pm 3^{\circ} \mathrm{C}$ for 24 hours, with 3 replications (ASABE, 2010).

Grain moisture content was approximately 0.21 (decimal db). The grains were divided into four samples, each with four subsamples, which were placed in Petri plates. The grains were placed uniformly on the plate, forming a layer according to grain thickness, where each subsample had an initial average weight of $22 \mathrm{~g}$.

The plates with subsamples were inserted in a BOD chamber, being exposed to drying air temperatures of $20,30,40$, and $50{ }^{\circ} \mathrm{C}$. Drying air relative humidity was monitored by two analog psychrometers, one placed on the laboratory bench and the other inside the BOD chamber. Subsamples were weighed on an analytical balance at 30-minute intervals until the moisture content ratio $(\mathrm{RX})$ was close to zero.

The RX calculation was performed by Equation 1.

$R X=\frac{\left(X-X_{e}\right)}{\left(X_{i}-X_{e}\right)}$

Wherein:

$\mathrm{RX}$ = product moisture ratio, dimensionless;

$\mathrm{X}=$ product moisture content, decimal $\mathrm{db}$;

$\mathrm{X}_{\mathrm{i}}=$ initial product moisture content, decimal $\mathrm{db}$;

$\mathrm{X}_{\mathrm{e}}=$ equilibrium product moisture content, decimal $\mathrm{db}$.

The mathematical models fitted to the RX data by means of nonlinear regression using the GaussNewton interaction, performed by the software Statistica version 7.0, at $5 \%$ confidence interval. The mathematical models commonly used for grain drying kinetics were applied (Rodovalho et al., 2015) (Table 1).

Table 1 - Mathematical models used to adjust the data obtained from drying kinetics.

\begin{tabular}{|c|c|c|}
\hline Model name & Model & Equation \\
\hline Diffusion approach & $R X=a \exp (-k t)+(1-a) \exp (-k b t)$ & (2) \\
\hline Two terms & $R X=a \exp (-k t)+b \exp (-k 1 t)$ & (3) \\
\hline Exponential of two terms & $R X=a \exp (-k t)+(1-a) \exp (-k a t)$ & (4) \\
\hline Henderson and Pabis & $R X=a \exp (-k t)$ & (5) \\
\hline Henderson and Pabis Modified & $R X=a \exp (-k t)+b \exp (-k 1 t)+c \exp (-k 2 t)$ & (6) \\
\hline Logarithmic & $R X=a \exp (-k t)+b$ & (7) \\
\hline Midilli & $R X=a \exp (-k(t b))+c t$ & (8) \\
\hline Midilli Modified & $R X=\exp (-k(t n))+a t$ & (9) \\
\hline Newton & $R X=\exp (-k t)$ & (10) \\
\hline Page & $R X=\exp (-k(t n))$ & (11) \\
\hline
\end{tabular}

Wherein: RX - product moisture ratio (dimensionless); $\mathrm{t}$ - drying time, hours; $\mathrm{k}$ - drying coefficient; $\mathrm{a}, \mathrm{b}, \mathrm{c}$ and $\mathrm{n}$ - model constants. 
For the selection of the mathematical model that best fitted the experimental data of soybean grains, the following criteria were considered: relative average error $(P)$ less than 10\% (Equation 12), the lowest estimated mean error (SE) (Equation 13), the lowest chi-square value (X2) (Equation 14), the magnitude of the coefficient of determination $\left(R^{2}\right)$, and the residual distribution (Resende et al., 2010).

$P=\frac{100}{n} \sum_{i=1}^{n}\left(\frac{|Y-\hat{Y}|}{Y}\right)$

$S E=\sqrt{\frac{\sum_{i=1}^{n}(Y-\widehat{Y})^{2}}{D F R}}$

$X^{2}=\sum_{i=1}^{n} \frac{(Y-\widehat{Y})^{2}}{D F R}$

Wherein:

$\mathrm{P}=$ relative mean error;

$\mathrm{n}=$ number of experimental observations;

$\mathrm{Y}=$ value observed experimentally;

$\hat{Y}=$ value estimated by the model;

$\mathrm{SE}=$ estimated mean error;

DFR $=$ degrees of freedom of the model (number of experimental observations minus the number of model coefficients);

$X^{2}=$ chi-square;

Soybean volume was obtained with a digital caliper, measuring the three orthogonal axes (length, width, and thickness), as proposed by Mohsenin (1986). This procedure was performed on 50 grains before drying. The average of the axes was calculated according to Equation 15.

$\mathrm{V}_{\mathrm{g}}=\frac{\pi \mathrm{ABC}}{6}$

Wherein:

$\mathrm{V}_{\mathrm{g}}=$ grain volume, $\mathrm{m}^{3}$;

$A=$ largest grain axis, $m$;

$\mathrm{B}=$ intermediate grain axis, $\mathrm{m}$;

$\mathrm{C}=$ smallest grain axis, $\mathrm{m}$.

From the orthogonal axes obtained, the liquid diffusion model for spheres fitted the experimental data of soybean grain drying for the determination of the effective diffusion coefficient (Def), with approximation of 8 terms, using Equation 16. According to Brooker et al. (1992), this equation considers the geometric shape of the grain as spherical, disregarding the volumetric grain contraction and considering the moisture content boundary condition on the grain surface.

$R X=\frac{X-X_{e}}{X_{i}-X_{e}}=\frac{6}{\pi^{2}} \sum_{n=1}^{\infty} \frac{1}{n^{2}} \exp \left[-\frac{n^{2} \pi^{2} \text { Def } t}{R_{e}^{2}}\right]$
Wherein:

$\mathrm{t}=$ time, $\mathrm{s}$;

$\mathrm{n}=$ number of terms;

Def = liquid diffusion coefficient, $\mathrm{m}^{2} \mathrm{~s}^{-1}$;

$R_{e}=$ equivalent radius, $\mathrm{m}\left(2.95 \times 10^{-3} \mathrm{~m}\right)$.

The influence of drying air temperature on Def was evaluated using the Arrhenius equation, represented by Equation 17.

Def $=D_{0} \exp \left[-\frac{E_{a}}{R \cdot T_{a}}\right]$

Wherein:

$\mathrm{D}_{0}=$ pre-exponential factor, $\mathrm{m}^{2} \mathrm{~s}^{-1}$;

$E_{a}=$ activation energy, $\mathrm{J} \mathrm{mol}^{-1}$;

$\mathrm{R}=$ universal gas constant, $8.314 \mathrm{~J} \mathrm{~mol}^{-1} \mathrm{~K}^{-1}$;

$\mathrm{T}_{\mathrm{a}}=$ absolute temperature, $\mathrm{K}$.

The thermodynamic properties enthalpy $(\Delta \mathrm{H})$, entropy $(\Delta S)$, and Gibbs free energy $(\Delta G)$ were determined from the values of $E_{a}$ and $D_{0}$ obtained by fitting the Arrhenius model (Jideani \& Mpotokwana, 2009). These thermodynamic properties were calculated according to Equations 18, 19, and 20 for $\Delta \mathrm{H}, \Delta \mathrm{S}$, and $\Delta \mathrm{G}$, respectively.

$\Delta \mathrm{H}=\mathrm{E}_{\mathrm{a}}-\mathrm{R} \mathrm{T}_{\mathrm{a}}$

$\Delta S=R\left[\ln \left(D_{0}\right)-\ln \left(\frac{k_{B}}{h_{P}}\right)-\ln \left(T_{a}\right)\right]$

$\Delta \mathrm{G}=\Delta \mathrm{H}-\mathrm{T}_{\mathrm{a}} \Delta \mathrm{S}$

Wherein:

$\Delta \mathrm{H}=$ enthalpy, $\mathrm{J} \mathrm{mol}^{-1}$;

$\Delta S=$ entropy, $\mathrm{J} \mathrm{mol}^{-1}$;

$\Delta G=$ Gibbs free energy, $\mathrm{J} \mathrm{mol}^{-1}$;

$\mathrm{k}_{\mathrm{B}}=$ Boltzmann constant, $1.3810^{-23} \mathrm{~J} \mathrm{~K}^{-1}$;

$\mathrm{h}_{\mathrm{P}}=$ Planck constant, $6.62610^{-34} \mathrm{~J} \mathrm{~s}$.

\section{Results and discussions}

According to Araujo et al. (2017), the fitting of the models cannot be classified only by the coefficient of determination $\left(R^{2}\right)$, requiring the evaluation of more statistical parameters such as $\mathrm{P}, \mathrm{SE}, \mathrm{X}^{2}$, and the residual distribution. The evaluations of each statistical parameter follow the prescription applied to each experimental result of the mathematical models (Table 2). It is noteworthy that $P$ values higher than $10 \%$ are classified as inappropriate for drying kinetics (Mohapatra \& Rao, 2005). In turn, the closer to zero are the SE values, the better the fitting of the experimental data (Oliveira et al., 2012). According to these considerations, the Midilli model showed the best results compared to the other fitted models for presenting the lowest $P$ values (between 1.9 and $3 \%$ ) and the lowest 
SE values (between $1.1310^{-8}$ and $7.5310^{-10}$ ) at the studied drying air temperatures (Table 2). Moreover, as observed for SE, the closer to zero is the $X^{2}$ value, the better the model fit (Draper \& Smith, 1998). For this variable, all models presented results close to zero, but the Midilli model still had the lowest values (between $1.1310^{-8}$ and $\left.7.5310^{-10}\right)$.

Table 2 - Coefficient of determination $\left(R^{2}\right)$, relative average error $(P)$, estimated mean error (SE), chi-square test $\left(\mathrm{X}^{2}\right)$ and residual distribution (Dist.) as adjustment criteria of the models to the experimental data of the drying kinetics of soybeans, obtained at air temperatures of $20,30,40$ and $50{ }^{\circ} \mathrm{C}$.

\begin{tabular}{|c|c|c|c|c|c|c|}
\hline Models & Temp. $\left({ }^{\circ} \mathrm{C}\right)$ & $x^{2}$ & $\mathrm{P}(\%)$ & SE & $\mathrm{R}^{2}$ & Dist. \\
\hline \multirow{4}{*}{ Diffusion approach } & 20 & $1.27 .10^{-8}$ & 2.8 & $1.13 .10^{-4}$ & 0.99 & ${ }^{*} \mathrm{R}$ \\
\hline & 30 & $2.52 .10^{-8}$ & 9.5 & $1.59 .10^{-4}$ & 0.99 & $\mathrm{R}$ \\
\hline & 40 & $1.27 .10^{-6}$ & 10.1 & $1.13 .10^{-3}$ & 0.87 & $\mathrm{R}$ \\
\hline & 50 & $1.51 .10^{-6}$ & 14.2 & $1.23 .10^{-3}$ & 0.83 & $R$ \\
\hline \multirow{4}{*}{ Two terms } & 20 & $9.75 .10^{-9}$ & 2.7 & $9.87 .10^{-5}$ & 0.99 & $\mathrm{R}$ \\
\hline & 30 & $2.75 .10^{-8}$ & 8.2 & $1.66 .10^{-4}$ & 0.99 & $R$ \\
\hline & 40 & $1.23 .10^{-8}$ & 8.6 & $1.11 .10^{-4}$ & 0.98 & $\mathrm{R}$ \\
\hline & 50 & $4.06 .10^{-9}$ & 13.7 & $6.37 .10^{-5}$ & 0.99 & $\mathrm{R}$ \\
\hline \multirow{4}{*}{$\begin{array}{l}\text { Exponential of two } \\
\text { terms }\end{array}$} & 20 & $2.27 .10^{-7}$ & 9.8 & $4.76 .10^{-4}$ & 0.98 & $R$ \\
\hline & 30 & $2.62 .10^{-8}$ & 9.3 & $1.62 .10^{-4}$ & 0.99 & $\mathrm{R}$ \\
\hline & 40 & $2.62 .10^{-6}$ & 8.5 & $1.62 .10^{-3}$ & 0.81 & ${ }^{*} \mathrm{~B}$ \\
\hline & 50 & $7.61 .10^{-6}$ & 18.3 & $2.76 .10^{-3}$ & 0.68 & B \\
\hline \multirow{4}{*}{$\begin{array}{l}\text { Henderson and } \\
\text { Pabis }\end{array}$} & 20 & $2.23 .10^{-7}$ & 9.8 & $4.73 .10^{-4}$ & 0.98 & $\mathrm{R}$ \\
\hline & 30 & $2.75 .10^{-8}$ & 8.2 & $1.66 .10^{-4}$ & 0.99 & $\mathrm{R}$ \\
\hline & 40 & $1.23 .10^{-8}$ & 8.6 & $1.11 .10^{-4}$ & 0.98 & $\mathrm{R}$ \\
\hline & 50 & $1.11 .10^{-7}$ & 9.9 & $3.33 .10^{-4}$ & 0.96 & B \\
\hline \multirow{4}{*}{$\begin{array}{l}\text { Henderson and } \\
\text { Pabis Modified }\end{array}$} & 20 & $2.23 .10^{-7}$ & 9.8 & $4.72 .10^{-4}$ & 0.98 & $\mathrm{R}$ \\
\hline & 30 & $2.53 .10^{-8}$ & 8.9 & $1.59 .10^{-4}$ & 0.99 & $\mathrm{R}$ \\
\hline & 40 & $1.33 .10^{-8}$ & 9.6 & $1.15 .10^{-4}$ & 0.98 & $\mathrm{R}$ \\
\hline & 50 & $4.06 .10^{-9}$ & 13.7 & $6.37 .10^{-5}$ & 0.99 & $\mathrm{R}$ \\
\hline \multirow{4}{*}{ Logarithmic } & 20 & $1.87 .10^{-8}$ & 3.4 & $1.37 .10^{-04}$ & 0.99 & $\mathrm{R}$ \\
\hline & 30 & $2.49 .10^{-8}$ & 7.5 & $1.58 .10^{-4}$ & 0.99 & $\mathrm{R}$ \\
\hline & 40 & $6.23 .10^{-9}$ & 5.4 & $7.90 .10^{-5}$ & 0.98 & $\mathrm{R}$ \\
\hline & 50 & $1.16 .10^{-7}$ & 15.4 & $3.41 .10^{-4}$ & 0.96 & B \\
\hline \multirow{4}{*}{ Midili } & 20 & $1.13 .10^{-8}$ & 3.0 & $1.06 .10^{-4}$ & 0.99 & $\mathrm{R}$ \\
\hline & 30 & $5.12 .10^{-9}$ & 2.6 & $7.16 .10^{-5}$ & 0.99 & $\mathrm{R}$ \\
\hline & 40 & $7.53 .10^{-10}$ & 1.9 & $2.74 .10^{-5}$ & 0.99 & $\mathrm{R}$ \\
\hline & 50 & $2.33 .10^{-10}$ & 2.8 & $1.53 .10^{-5}$ & 0.99 & $\mathrm{R}$ \\
\hline \multirow{4}{*}{ Midilli Modified } & 20 & $1.22 .10^{-8}$ & 3.0 & $1.10 .10^{-4}$ & 0.99 & $\mathrm{R}$ \\
\hline & 30 & $5.09 .10^{-9}$ & 2.6 & $7.14 .10^{-5}$ & 0.99 & $\mathrm{R}$ \\
\hline & 40 & $1.08 .10^{-6}$ & 2.7 & $1.04 .10^{-3}$ & 0.88 & $\mathrm{R}$ \\
\hline & 50 & $1.41 .10^{-6}$ & 4.7 & $1.19 .10^{-3}$ & 0.84 & $\mathrm{R}$ \\
\hline \multirow{4}{*}{ Newton } & 20 & $2.11 .10^{-7}$ & 9.6 & $4.60 .10^{-4}$ & 0.98 & $\mathrm{R}$ \\
\hline & 30 & $3.59 .10^{-8}$ & 7.9 & $1.90 .10^{-4}$ & 0.99 & $\mathrm{R}$ \\
\hline & 40 & $5.84 .10^{-6}$ & 12.8 & $2.42 .10^{-3}$ & 0.74 & B \\
\hline & 50 & $1.43 .10^{-5}$ & 25.5 & $3.78 .10^{-3}$ & 0.58 & B \\
\hline \multirow{4}{*}{ Page } & 20 & $1.55 .10^{-7}$ & 8.3 & $3.94 .10^{-4}$ & 0.98 & $\mathrm{R}$ \\
\hline & 30 & $3.02 .10^{-8}$ & 10.5 & $1.74 .10^{-4}$ & 0.99 & $\mathrm{R}$ \\
\hline & 40 & $1.76 .10^{-6}$ & 17.2 & $1.33 .10^{-3}$ & 0.86 & $R$ \\
\hline & 50 & $2.24 .10^{-6}$ & 28.1 & $1.50 .10^{-3}$ & 0.81 & B \\
\hline
\end{tabular}

${ }^{*} \mathrm{R}$ : random residual distribution;" B: Biased residual distribution.

The Midilli model showed random residual distribution (Table 2 and Figure 1), thus resulting in better fittings to the experimental data of soybean grain drying. The Newton model was the least satisfactory, with random residual distribution for the temperatures of 20 and $30{ }^{\circ} \mathrm{C}$, and biased residual distribution for the temperatures of 40 and $50{ }^{\circ} \mathrm{C}$, which were not suitable for drying (Table 2 and Figure 2). The $\mathrm{R}^{2}$ results for the temperatures of 20 and $30^{\circ} \mathrm{C}$ were higher than 0.98 , and varied more for the temperatures of 40 and $50^{\circ} \mathrm{C}$, reaching up to 0.68 . The Midilli model stands out for presenting the highest magnitude of $R^{2}(0.99)$ for all temperatures studied (Table 2).

Considering the adopted statistical criteria, the Midilli model is the most recommended to represent the phenomenon of soybean grain kinetics in the studied conditions. This model is commonly used in the fitting of drying data for grains and cereals such as cowpea 
(Camicia et al., 2015) and for pigeon pea (Cajanus cajan L.) (Silva et al., 2014). The Midilli model was also recommended in the study by Botelho et al. (2018), who

(a)

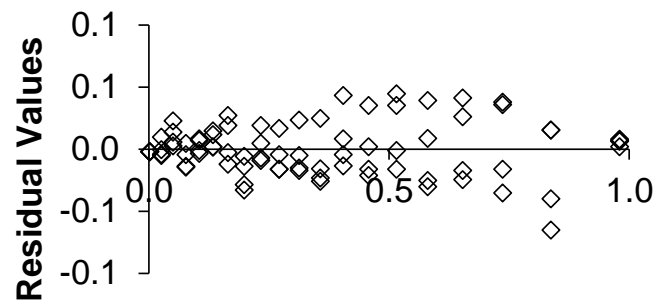

Preditcted Values

(c)

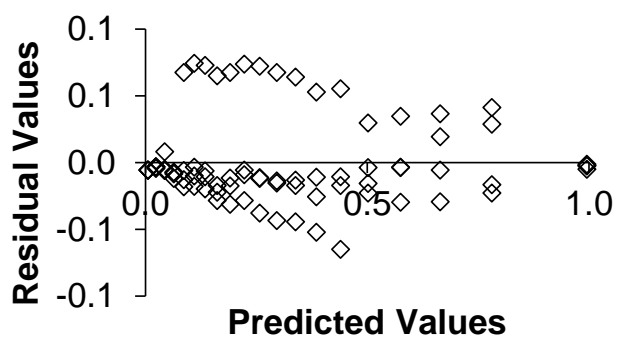

analyzed the kinetics of drying in a forced ventilation oven at temperatures ranging from 40 to $70^{\circ} \mathrm{C}$.

(b)

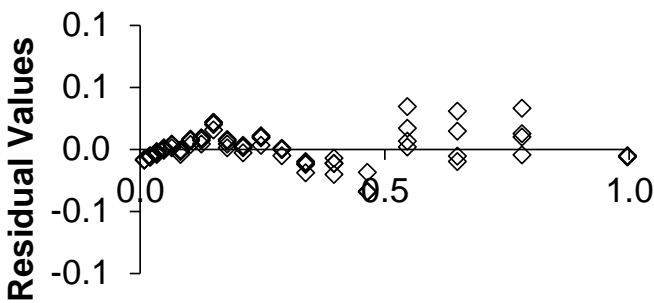

Predicted Values

(d)

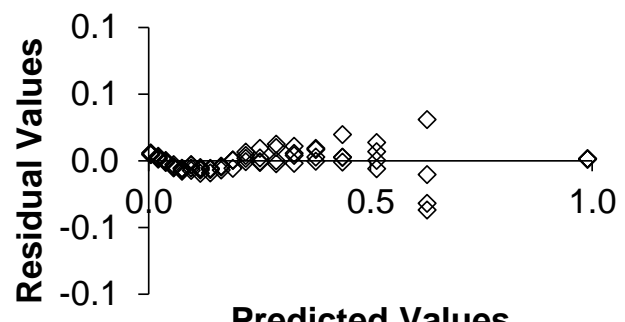

Predicted Values

Figure 1 - Distribution of residues by the Midilli model for soybeans at drying air temperatures of $20^{\circ} \mathrm{C}(\mathrm{a})$, $30^{\circ} \mathrm{C}(\mathrm{b}), 40^{\circ} \mathrm{C}(\mathrm{c})$ and $50^{\circ} \mathrm{C}(\mathrm{d})$.

(a)

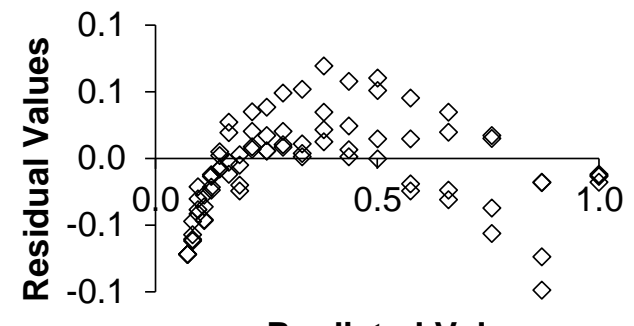

(c)

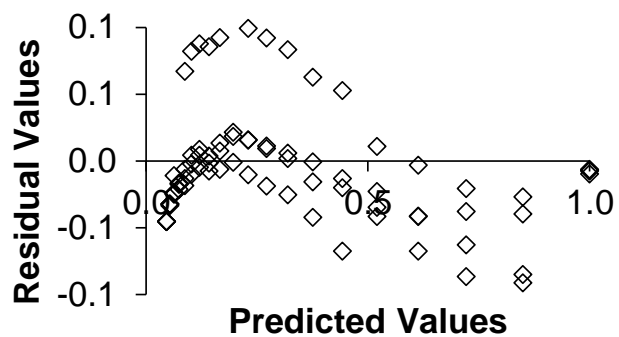

(b)

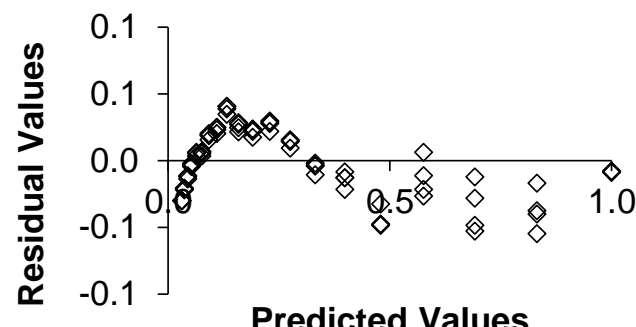

(d)

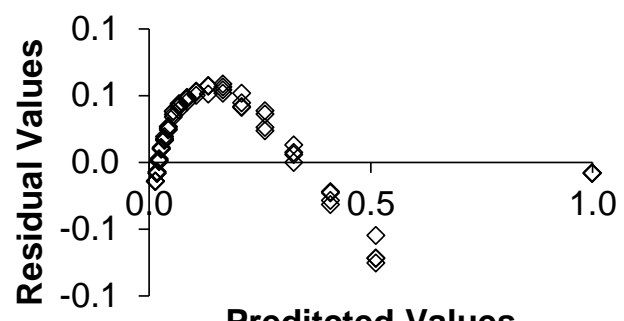

Figure 2 - Distribution of residues by the Newton model for soybeans at drying air temperatures of $20{ }^{\circ} \mathrm{C}(\mathrm{a})$, $30^{\circ} \mathrm{C}(\mathrm{b}), 40^{\circ} \mathrm{C}(\mathrm{c})$ and $50^{\circ} \mathrm{C}(\mathrm{d})$.

Midilli coefficients were significant at $5 \%$ probability by the t test. Model coefficients "a", "b", and "k" did not show a trend with the increase in temperature, but the coefficient " $n$ " decreased according to the increase in temperature (Table 3). In grain drying, the coefficient " $n$ " tends to decrease with increasing temperature, since the pressure difference between the air vapor and the grain tends to result in a greater removal of water (Silva et al., 2014). 
Table 3 - Coefficient of the Midilli model for drying soybeans for different drying air temperatures.

\begin{tabular}{lccccc}
\hline \multirow{2}{*}{ Model } & Temp. & \multicolumn{3}{c}{ Coefficients } \\
\cline { 3 - 6 } & $\left(\mathrm{C}^{\circ}\right)$ & $\mathrm{a}$ & $\mathrm{b}$ & $\mathrm{n}$ & $\mathrm{k}$ \\
\hline \multirow{3}{*}{ Midilli } & 20 & $0.9804^{*}$ & $-0.0193^{*}$ & $0.825^{*}$ & $0.2593^{*}$ \\
& 30 & $0.9974^{*}$ & $-0.0069^{*}$ & $0.809^{\star}$ & $0.4192^{*}$ \\
& 40 & $0.7203^{*}$ & $-0.0105^{*}$ & $0.7188^{\star}$ & $0.3834^{*}$ \\
& 50 & $0.6965^{*}$ & $-0.0115^{*}$ & $0.4981^{*}$ & $0.6239^{*}$ \\
\hline
\end{tabular}

* Significant by $t$ test $(p \leq 0.05)$.

The values in Figure 3 correspond to the drying kinetics of soybean grains in the Midilli model, to which moisture ratio fitted better than drying time. In the same $\mathrm{RX}$, the higher the temperature, the shorter the drying time. This fact was also observed by Resende et al. (2010) when analyzing the drying kinetics of adzuki bean (Vigna angularis), and Botelho et al. (2018) when analyzing the same phenomenon in soybean grains. This behavior occurs because the higher the drying air temperature, the lower the grain moisture content due to the increase in the water potential gradient between the grain and the air (Silva et al., 2014).

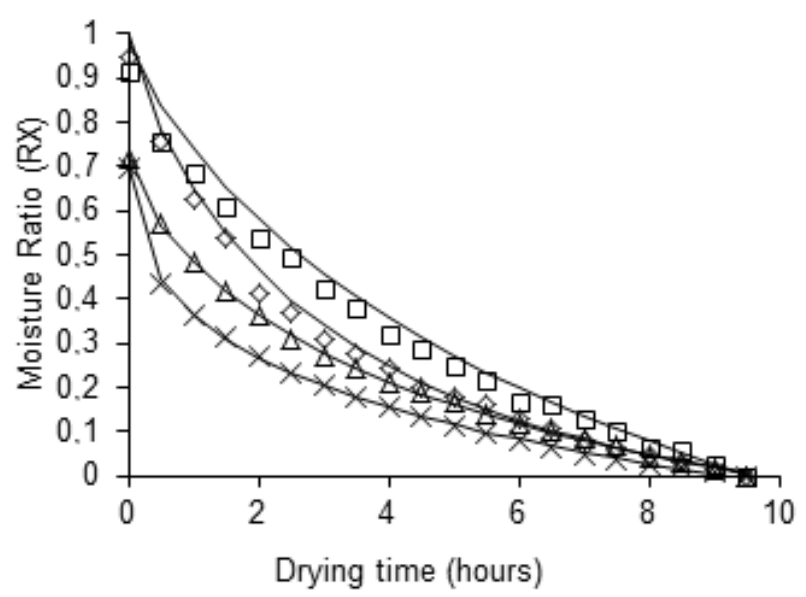

- Predicted

- Observed $20^{\circ} \mathrm{C}$

$\diamond$ Observed $30^{\circ} \mathrm{C}$

$\triangle$ Observed $40^{\circ} \mathrm{C}$

$\times$ Observed $50^{\circ} \mathrm{C}$

Figure 3 - Midilli model adjusted to RX data obtained from drying soybeans at different drying air temperatures.

During drying, effective diffusion (Def) increased along with temperature, reaching $2.264210^{-9}$, $2.642210^{-9}, 3.953910^{-9}$, and $5.632510^{-9}\left(\mathrm{~m}^{2} \mathrm{~s}^{-1}\right)$ at temperatures of $20,30,40$, and $50^{\circ} \mathrm{C}$, respectively (Figures $4 \mathrm{~A}$ and $4 \mathrm{~B}$ ). Almeida et al. (2009) observed that effective diffusion values increased linearly with the increase of drying temperature in adzuki bean grain. Jangam et al. (2010) state that grains and other plant materials have Def values from $10^{-13}$ to $10^{-7}$. Therefore, the results are similar to those in the literature. (a)

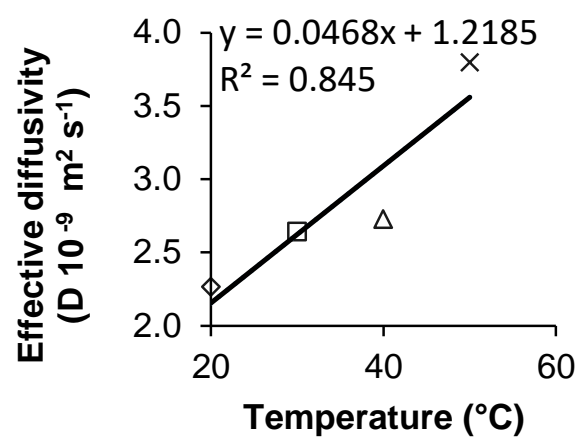

(b)

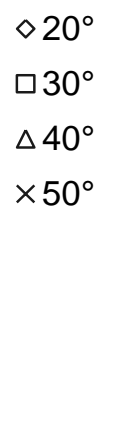

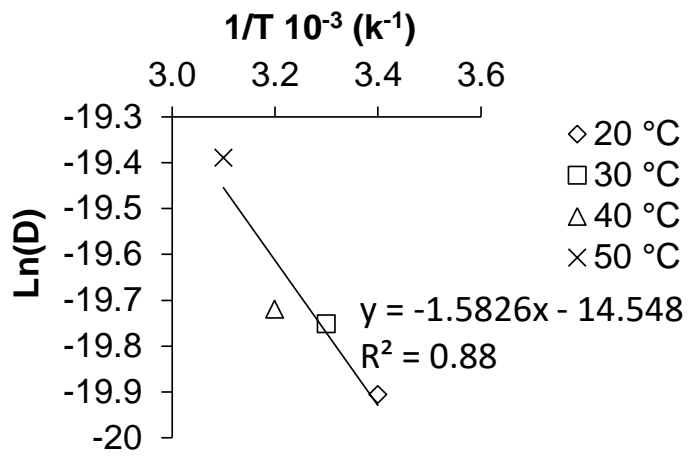

Figure 4 - Effective diffusivity coefficient of water $\left(\mathrm{m}^{2} \mathrm{~s}^{-1}\right)$ obtained when drying soybeans for different drying air temperatures. 
The activation energy $\left(E_{a}\right)$ obtained by fitting the Ahrrenius model to the Def data was $26.80 \mathrm{~kJ} \mathrm{~mol}^{-1}$. This result is within the values recommended in the literature for agricultural products. According to Zogzas et al. (1996), these values can range from $12.7 \mathrm{~kJ} \mathrm{~mol}^{-1}$ to $110 \mathrm{~kJ} \mathrm{~mol}^{-1}$. Morais et al. (2013) observed similar $\mathrm{E}_{\mathrm{a}}$ values for cowpea grain $\left(27.16 \mathrm{~kJ} \mathrm{~mol}^{-1}\right)$. Using temperatures of 40,50 , and $60^{\circ} \mathrm{C}$, Silva et al. (2008) obtained an $E_{a}$ of $26.9 \mathrm{~kJ} \mathrm{~mol}^{-1}$ in an experiment with grains of macassar bean (Vigna unguiculata L. Walp.). Corrêa et al. (2007) studied the drying of bean grains and define $E_{a}$ as the capacity of the water molecule to overcome an energy barrier during its migration from the interior to the surface of the grain; thus, the lower the $E_{a}$, the higher the water diffusivity.

Enthalpy $(\Delta \mathrm{H})$ decreased with increasing temperature (Table 4). Corrêa et al. (2010) also observed a reduction in enthalpy values as a function of the increase in temperature. The authors explain that the higher the temperature, the lower the energy expenditure for drying grains, which shows that the results obtained are within the recommended standard for enthalpy.

Table 4 - Thermodynamic properties, enthalpy $(\Delta H)$, entropy $(\Delta S)$ and Gibbs free energy $(\Delta G)$ obtained in drying soybeans at different drying air temperatures.

\begin{tabular}{lccc}
\hline Temp. $\left({ }^{\circ} \mathrm{C}\right)$ & $\Delta \mathrm{H}\left(\mathrm{kJ} \mathrm{mol}^{-1}\right)$ & $(\Delta \mathrm{S})\left(\mathrm{kJ} \mathrm{mol}^{-1}\right)$ & $\Delta \mathrm{G}\left(\mathrm{kJ} \mathrm{mol}^{-1}\right)$ \\
\hline 20 & 24.3702 & -0.3644 & 131.1465 \\
30 & 24.2870 & -0.3647 & 134.7921 \\
40 & 24.2039 & -0.3649 & 138.4405 \\
50 & 24.1208 & -0.3652 & 142.0915 \\
\hline
\end{tabular}

As expected, the entropy values (Tabela 4) decreased as the drying temperature increased. According to Araujo et al. (2017), the rise in temperature provides an increase in the partial pressure of water vapor in the product, consequently exciting water molecules. These factors increase the rate of water diffusion from the interior of the grain to the drying air, and decrease entropy.

The results for Gibbs free energy (Table 4) were opposite to those of enthalpy and entropy, increasing along with temperature, which corroborates Nkolo Meze'E et al. (2008). The authors obtained positive Gibbs free energy values, since drying was not spontaneous. In their study, the samples were initially exposed to an environment with higher relative humidity, being subsequently subjected to drying, decreasing moisture content.

\section{Conclusions}

The mathematical model of Midilli best fit the drying kinetics of soybean grains.

The activation energy was $26.80 \mathrm{~kJ} \mathrm{~mol}^{-1}$, standard for agricultural products.

As the drying air temperature rises, the effective diffusion coefficient increases from $2.264210^{-9}$ to $5.632510^{-9} \mathrm{~m}^{2} \mathrm{~s}^{-1}$, common values for grains.

The increase in drying air temperature increases Gibbs free energy while decreasing enthalpy and entropy, a behavior common to grains for different temperatures.

\section{Acknowledgements}

This research was supported by Instituto Federal Goiano (Campus Ceres), Fundação de Amparo à Pesquisa do Estado de Goiás (FAPEG) and Conselho Nacional de Desenvolvimento Científico e Tecnológico (CNPq).

\section{References}

Almeida DP, Resende O, Costa LM, Mendes UC, Sales JF (2009) Cinética de secagem do feijão adzuki (Vigna angularis). Global Science and Technology 2(1):72-83.

Araujo WD, Goneli ALD, Corrêa PC, Hartmann Filho, CP, Martins EAS (2017) Modelagem matemática da secagem dos frutos de amendoim em camada delgada. Revista Ciência Agronômica 48(3):448-457.

ASABE (2010) Moisture Measurement - Forages: Standard S358.2 DEC1988, R2008. In: American Society of Agricultural and Biological Engineers (Ed.). Standards, Engineering Practices, and Data. St. Joseph: ASABE, 684-685p.

Barrozo MAS, Sartori DJM, Freire JT (2004) A study of the statistical discrimination of the drying kinetics equations. Transaction Institution of Chemical Engineers, Food and Bioproducts Processing 82(3):219-225.

Botelho FM, Hoscher RH, Hauth MR, Botelho SCC (2018) Cinética de secagem de grãos de soja: influência varietal. Revista Engenharia na Agricultura (26)1:13-25.

Brooker DB, Bakker-Arkema, FW, Hall CW (1992) Drying and Storage of Grains and Oilseeds. Westport: The AVI Publishing Company. 450p.

Camicia RGM, Christ D, Coelho SEM, Camicia RFM (2015) Modelagem do processo de secagem de sementes de feijão-caupi. Revista Caatinga 28(3):206214.

Coêlho JD (2018) Produção de grãos - feijão, milho e soja: relatório do ano de 2018. Fortaleza: Escritório técnico de estudos econômicos do Nordeste - ETENE. 7p. Disponível em: ' http://www.bnb.gov.br/etene. Acesso em: 25 jan, 2019. 
CONAB (2020) Acompanhamento da safra brasileira de grãos: Quarto levantamento de janeiro do ano de 2020. Brasília: Companhia Nacional de Abastecimento. 19p. Disponível em: 'https://www.conab.gov.br/infoagro/safras/graos'. Acesso em: 22 jan, 2020.

Corrêa PC, Oliveira GHH, Botelho FM, Goneli ALD, Carvalho FM (2010) Modelagem matemática e determinação das propriedades termodinâmicas do café (Coffea arabica L.) durante o processo de secagem. Revista Ceres 57(5):595-601.

Corrêa PC, Resende O, Martinazzo AP, Goneli ALD, Botelho FM (2007) Modelagem matemática para a descrição do processo de secagem do feijão (Phaseolus vulgaris L.) em camadas delgadas. Engenharia Agrícola 27(2):501-510.

Draper NR, Smith H (1998) Applied regression analysis. New York: John Wiley \& Sons, 712p.

Jangam SV, Law CL, Mujumdar (2010) Drying of foods, vegetables and fruits. Singapore: National University of Singapore, 232p.

Jideani VA, Mpotokwana ASM (2009) Modeling of water absorption of botswana bambara varieties using Peleg's equation. Journal of Food Engineering p.182-188

Mohapatra D, Rao PS (2005) A thin layer drying model of parboiled wheat. Journal of Good Engineering 66(4):513-518.

Mohsenin, NN (1986) Physical properties of plant and animal materials. New York: Gordon and Breach Publishers, 841p.

Morais SJS, Devilla IA, Ferreira DA., Teixeira IR (2013) Modelagem matemática das curvas de secagem e coeficiente de difusão de grãos de feijão-caupi (Vigna unguiculata (L.) Walp.). Revista Ciência Agronômica 44(3):455-463.
Nkolo Meze'e, YN, Noah Ngamveng J. Bardet S (2008) Effect of enthalpy-entropy compensation during sorption of water vapour in tropical woods: the case of bubinga (Guibourtia Tessmanii J. L'Eonard; G. Pellegriniana J.L.). Thermochimica Acta 468(1-2): 1-5.

Oliveira DEC, Resende O, Smaniotto TAS, Campos RC, Chaves TH (2012) Cinética de secagem dos grãos de milho. Revista Brasileira de Milho e Sorgo 11(2):190201.

Resende O, Ferreira LU, Almeida DP (2010) Modelagem matemática para descrição da cinética de secagem do feijão adzuki (Vigna angularis). Revista Brasileira de Produtos Agroindustriais 12(2):171-178.

Ribeiro DM, Corrêa PC, Rodrigues DH, Goneli ALD (2005) Análise da variação das propriedades físicas dos grãos de soja durante o processo de secagem. Ciência e Tecnologia de Alimentos 25(3):611-617.

Rodovalho RS, Silva HW, Silva IL, Rossetto CAV (2015) Cinética de Secagem dos Grãos de Pimenta Bode. Global Science and Technology 8(2): 128-142.

Silva LMM, Sousa FC, Souza EP, Moreira MER, Mata C, Duarte MEM (2014) Modelos de predição da cinética de secagem dos grãos de guandu. Brazilian Journal of Food Technology 17 (4):310-318.

Silva WP, Mata MERM, Silva CDPS, Guedes MA, Lima AGB (2008) Determinação da difusividade e da energia de ativação para feijão macassar (Vigna unguiculata (L.) walp.), variedade sempre-verde, com base no comportamento da secagem. Engenharia Agrícola 28(2):325-333.

Zogzas NP, Maroulis ZB, Marinoskouris D (1996) Moisture diffusivity data compilation in foodstuffs. Drying Technology 14(10):2225-2253. 